\title{
Relationship Interests, Motivation and Attention Parents of Biology Student Learning Outcomes Race: Passage of Interest in SMA Negeri Percut Sei Tuan
}

\author{
Laina Zuhra' ${ }^{1}$, Melva Silitonga ${ }^{2}$, Mufti Subdibyo ${ }^{3}$ \\ ${ }^{1}$ Postgraduate Program in Universitas Negeri Medan, Indonesia \\ ${ }^{2,3}$ Universitas Negeri Medan, Indonesia \\ Lainasadissa@gmail.com
}

\section{Abstract}

This study aims to determine: (1) Biology learning outcomes of students; (2) Student interest in learning; (3) student motivation; (4) Parents' attention; (5) The relationship between interest, motivation and parental attention to student biology learning outcomes in the cross-interest group of class $X$ students. This research was conducted at SMA Negeri 2 Percut Sei Tuan in 2019. The research method is a descriptive correlational research method with a research sample of 100 students. determined by cluster random sampling (random sample class). The research instrument consisted of a cognitive learning outcome test, a student interest questionnaire, a student learning motivation questionnaire, and a student parent attention questionnaire that had been tested for validity, reliability, discrepancy and level of difficulty. Data were analyzed using correlation analysis techniques using SPSS 21.0 for windows. The results showed: (1) Cognitive learning outcomes of 74.08 which fall into the moderate category; (2) The level of student interest was 64.67 which was in the medium category; (3) The level of student motivation is 68.46 which belongs to the medium category; (4) The level of attention of the students' parents is 66.74 which is in the moderate category; (5) The significant relationship between student interest in learning, student motivation, and parents' attention to student cognitive learning outcomes with Sig $0.00<0.05$.
Keywords

parents' interest; motivation; attention

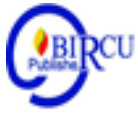

\section{Introduction}

All students want a good learning outcome, but to get all of that is not easy because considering the differences in each individual both in motivation, interests, character, aspirations and others that are owned by each student. With such differences, it will lead to the achievement of different learning outcomes. This can occur because of the many factors that affect learning outcomes, namely intelligence, talents, interests, motivation and the environment of students consisting of the school environment and the home environment or parents (Syah, 2015).

Interest (interest) is a tendency and high enthusiasm or great desire for something that is desired (Syah, 2015). Activities that are of interest to someone will be paid attention continuously with a sense of joy (Jirana and Nurmiati, 2015). Yusrizal et al., (2019) said that interest is a feeling of interest, attention, more desire that a person has for something, without any encouragement. Interest has a big effect on learning, because if the learning material being studied is not in accordance with the student's interest, students will not learn as well as 
possible, because there is no attraction for him to follow a particular lesson. Students will be reluctant to learn, because they do not get satisfaction in the lesson (Slameto, 2010). Interest is a factor that determines the achievement of learning goals. Because with an interest in learning in students it will make it easier for teachers to guide and direct students (Samben, 2014).

Learning interest is an individual's tendency to have a sense of pleasure without coercion so that it can cause changes in knowledge, skills and behavior (Yusrizal et al., 2019). Great interest in learning tends to produce high achievement, on the other hand, less interest in learning will result in low achievement, so it can be said that to be able to get high learning outcomes, a student must have a great interest in learning as well. Therefore, student interest in learning must be raised so that students are more interested in the lessons given by the teacher (Djamarah, 2006). Strong interest will lead to persistent, serious efforts and not easily give up in facing challenges, on the other hand, if someone's interest is low, their effort is also low in learning (Hasyim and Iqbal, 2018). Interest in learning is also one of the psychological factors that affect student learning and is also one of the main motivational tools that can arouse student enthusiasm for learning. This interest will stay and develop in him to get support from his environment in the form of experience (Yusrizal et al., 2019). Based on the results of research conducted by (Kambuaya, 2016) it shows that there is a significant influence between interests in student learning outcomes. In this case the indicators used in this interest variable are having a feeling of pleasure in each process, having a high level of interest, having attention to the process being passed and being actively involved in activities.

Interest is closely related to motivation because both are closely related to one another, interest can also affect the quality of student learning outcomes in certain fields of study as well as motivation (Syah, 2015). All students want good performance in school but are less motivated to study well. Motivation is a driving factor for individual activities. Motivation can involve emotions, anxiety or attitudes that inspire enthusiasm to try or do something. Children who have the desire to excel will have great motivation to learn if the support from parents is to pay attention to learning (Dumanauw, 2017). One of the factors that are related to the success of a child's learning achievement is the active role of parents in the child's learning process. Responsibility and active participation of parents and teachers will provide guidance and best education for their children, so expect her to achieve optimal learning results.

The role of people in the learning process at home will have an influence on children's learning outcomes. The achievement of learning outcomes is certainly a very decisive value for the achievement of children in school (Miranti, et al . 2017). If parents pay less attention to their children in learning, their motivation to learn will decrease. Parents think that what is important is that it is enough to send their children to school, without guiding their children to study at home. Parents who pay little or no attention to their children's education, for example they are indifferent to their children's learning, do not pay attention to their children's interests and needs in learning, manage their learning time, do not provide or complete learning tools, do not pay attention to their children learning or not, do not want to know how their child's learning progress, difficulties experienced in learning and others can cause children not to or less succeed in learning.

Dwidayani in Sitorus (2019) states that learning outcomes are measures of success or failure of students after taking teaching and learning activities both in terms of effective, psychomotor, and cognitive which includes knowledge (memory, understanding, application (application). 


\section{Review of Literatures}

\subsection{Interests}

Interest (interest) is a tendency and high enthusiasm or great desire for something that is desired (Syah, 2015). Crow \& Crow (in Yusrizal et al., 2019) says that interest is related to the style of movement that encourages a person to face or deal with people, objects, activities, experiences that are stimulated by the activity itself. Interest is also a constant tendency to pay attention to and remember some activities. Activities that are of interest to a person are paid attention continuously accompanied by pleasure and it is from pleasure that satisfaction arises in a certain matter. Interest has a big effect on learning, because if the learning material being studied is not in accordance with the student's interest, students will not learn as well as possible, because there is no attraction for him to follow a particular lesson. Students will be reluctant to learn, they do not get satisfaction in the lesson. Learning materials that attract students' interest are easier to learn and store because of the interest in adding learning activities to these students (Slameto, 2010).

Some educational experts argue that the most effective way to generate interest in a new subject is to use existing student interests. In addition to taking advantage of existing interests, teachers also try to form new interests in these students. This can be achieved by providing information to students about the relationship between a teaching material that will be provided with past teaching materials, describing its use for students in the future. Another way that can be used to increase student interest is to link the teaching material with a sensational story that most students already know.

\subsection{Motivation}

Every action, including learning action, is driven by something or several motivations. Motivation or also known as encouragement or need is something that is in the individual or student that encourages him to act to achieve a certain goal. (Ibrahim, et al . 2010). So, motivation is closely related to the goals to be achieved in a particular lesson. In determining the goal, it can be realized or not, but to achieve that goal it is necessary to act, while what causes action is the motivation itself as a driving force or impetus. Motivation is strength, but it is not an easily observable substance (Makmun, 2012).

In the learning process, it is necessary to pay attention to what can encourage students to learn well or have the motivation to think and focus, plan and carry out activities related to or support learning (Yusrizal, 2020). Motivations can also be instilled in students by providing exercises or habits which are sometimes also influenced by environmental conditions. Motivation is indispensable in learning, in forming a strong motivation it can be carried out with the practice of habits and strengthening environmental influences as well (Slameto, 2010). So motivation is the urge, stimulation, movement, generator that arises in a person consciously or unconsciously to carry out an action with a specific purpose.

There are several efforts that teachers can make to stimulate student learning. First, using a variety of teaching methods and media. With a variety of methods and media, boredom can be reduced or eliminated. Second, choose materials that interest the students needed. Something that is needed will attract attention, thereby arousing a motive for studying it. Third, provide intermediate targets. The ultimate goal of studying is to pass an exam or go up a class. The final target was only achieved at the end of the year. In order to 
generate learning motives, intermediate targets are held, such as semester exams, midterms, daily tests, quizzes and so on.

\subsection{Parents' Attention}

The family is an informal educational institution (outside school) that is recognized for its existence in the world of education. Its role is no less important than formal and informal institutions. Even before a student enters a school, he or she has received an education in the family. Education in the family environment is the most important education because the family is the smallest community unit that is the first to be recognized by a child. It is in this family environment that a child learns to socialize with other family members. Every child grows and develops, learns and hones skills, even they gain knowledge, interests, motivation in the family environment.

One of the factors that are related to the success of a child's learning achievement is the active role of parents in the child's learning process. The responsibility and active role of parents and teachers will provide the best guidance and education for their children, so that they are expected to achieve optimal learning outcomes. The role of people in the learning process at home will have an influence on children's learning outcomes. The achievement of learning outcomes is certainly a very decisive value for the achievement of children in school (Miranti, et al . 2017).

The way people know how to educate and care for their children also affects children's learning and achievement. Sutjipto Wirodjojo stated that the family is the first and foremost educational institution. Looking at the statement above, it can be understood how important the role of the family is in their children's education. The way parents educate their children will also affect their learning.

Parents who pay little or no attention to their children's education, for example they are indifferent to their children's learning, do not pay attention to their children's interests and needs in learning, manage their learning time, do not provide or complete learning tools, do not pay attention to their children learning or not, do not want to know how their child's learning progress, difficulties experienced in learning and others can cause children not to or less succeed in learning. Learning outcomes are a form of achievement students as well as a symbol of the success of educators in learning students (Yusuf in Sitorus (2019).

\section{Research Methods}

This type of research is a descriptive correlation, which is to determine the relationship between interest, motivation and parental attention to student biology learning outcomes in cross-interest clumps at SMA Negeri Percut Sei Tuan. The samples in this study were all students of class X MIA (Mathematics and natural sciences) and IIS (social sciences) public high schools located in Percut Sei Tuan Subdistrict in the 2019-2020 learning year who took a number of specializations in biology 100 students. The data collection techniques used were questionnaires and learning outcomes tests. The data analysis technique used in this research is inferential statistical techniques. To test the research hypothesis between the variables $\mathrm{X}_{1}$ and $\mathrm{Y}$; $\mathrm{X}_{2}$ with $\mathrm{Y}$; and $\mathrm{X}_{1}$ with $\mathrm{X}_{2}$ used the correlation technique using the Pearson Product Moment formula . 


\section{Results and Discussion}

\subsection{Results}

\section{a. Description of Student Learning Outcomes}

Based on research that has been conducted from 100 respondents in SMA Negeri Sekecamatan Percut Sei Tuan, the statistical data description of the average score of cognitive learning outcomes is 74.08 with a standard deviation of 10.73 which is categorized as moderate.

\section{b. Description of Student Interest in Learning}

Based on research that has been conducted from 100 respondents in SMA Negeri Sekecamat Percut Sei Tuan, the average score of student interest is 64.67 with a standard deviation of 12.51 which is categorized as moderate.

\section{c. Description of Student Motivation}

Based on research that has been conducted from 100 respondents in SMA Negeri Sekecamatan Percut Sei Tuan, the average score of student motivation is 68.46 with a standard deviation of 10.61 which is categorized as moderate.

\section{d. Description of Parents' Attention}

Based on research that has been conducted from 100 respondents in SMA Negeri Sekecamatan Percut Sei Tuan, and for the average score of parental attention is 66.74 with a standard deviation of 10.46 which is categorized as moderate.

\section{e. Interests, Motivation and Attention of Parents to Student Learning Outcomes}

Based on the research data obtained by each of the 100 respondents of SMA Negeri in Percut Sei Tuan, it is known that the average value of the level of student interest is 64.67 which is classified as in the moderate category, student motivation is 68.46 which is classified as medium category, the level of attention of the parents of students 66.74 which is included in the moderate category, cognitive learning outcomes of 74.08 which belong to the moderate category.

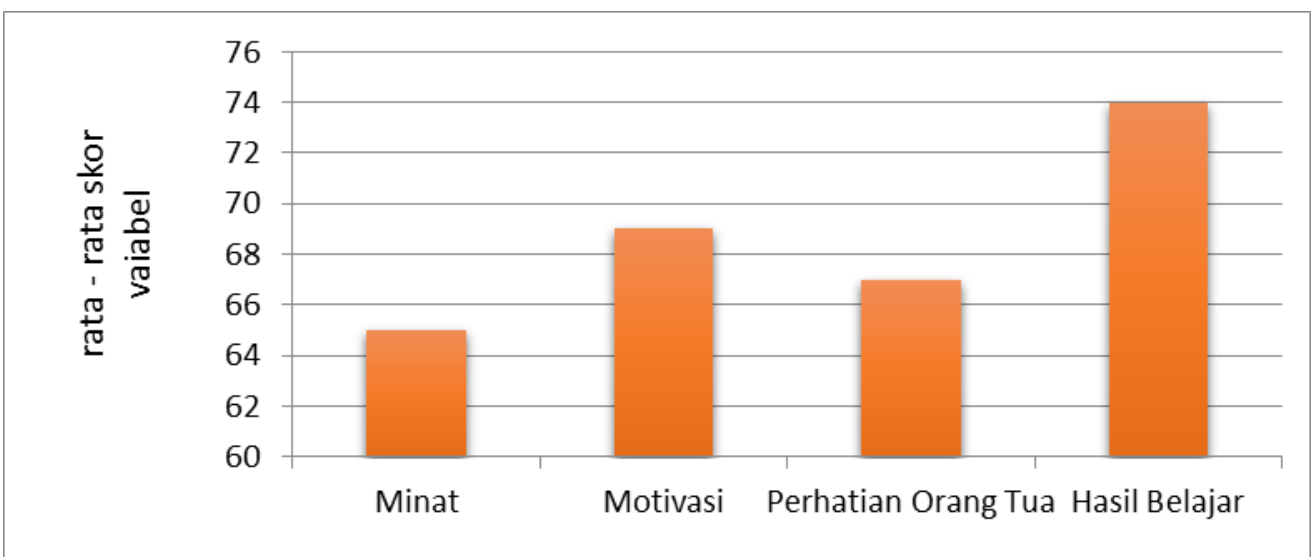

Figure 1. Levels of Student Learning Outcomes, Interests, Motivation and Attention of Parents 


\section{f. Hypothesis Testing}

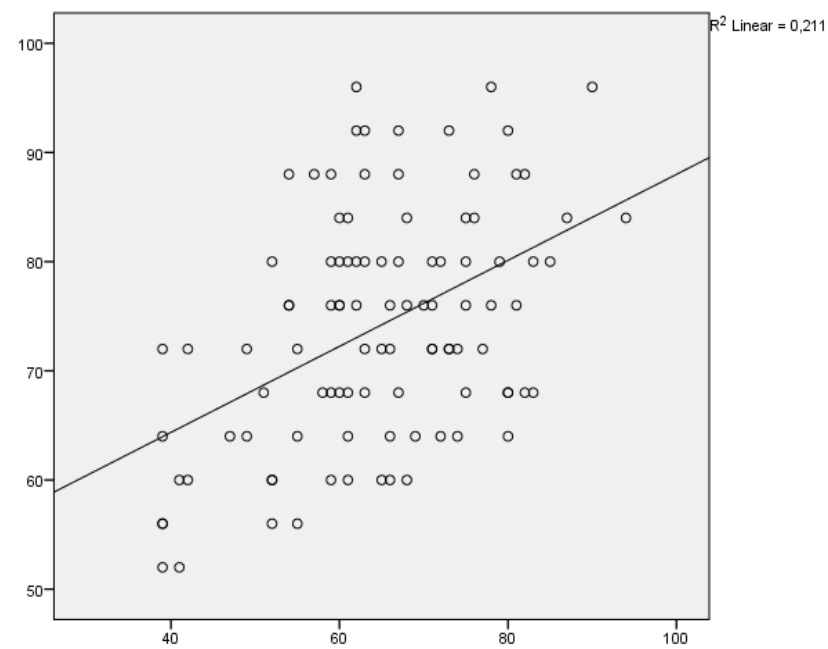

Figure 2. Relationship of Interests to Biological Cognitive Learning Outcomes

Based on the results of the regression test on the results of student interest in learning and cognitive learning outcomes in Figure 2., it is known that the price of $r=0.459$, which means that student interest in learning is related to student cognitive biology learning outcomes where the level of closeness of the relationship between variables $\mathrm{X}_{1}$ and $\mathrm{Y}$ is included in the medium category with a Sig value of $0,00<0.05$. The value of the correlation coefficient $\left(\mathrm{R}^{2}{ }_{X 1 Y}\right)$ is 0,211 , so the contribution of students' interest towards the cognitive learning biology by $21.1 \%$.

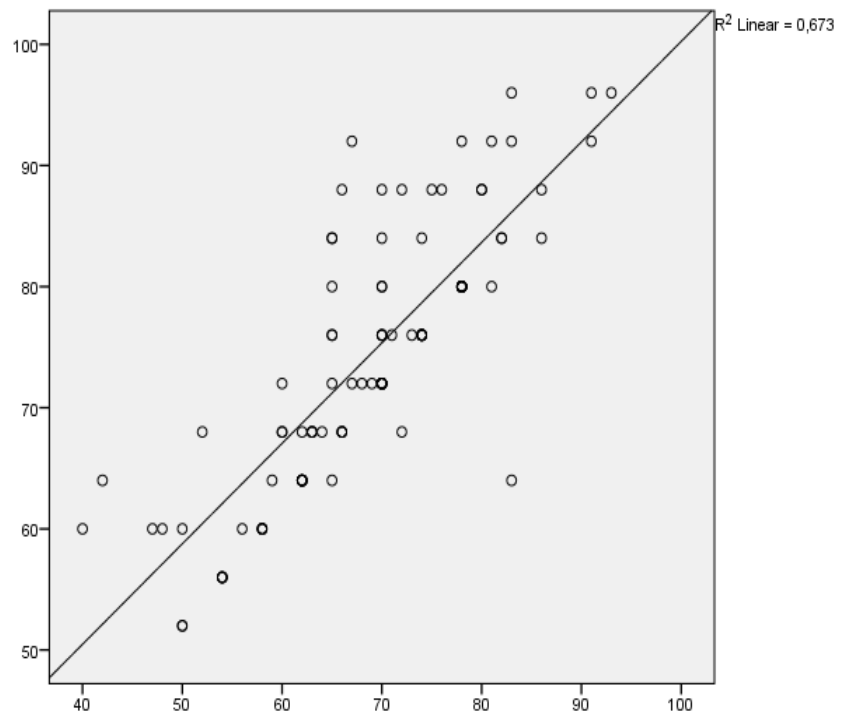

Figure 3. The Relationship between Motivation and Biological Cognitive Learning

Outcomes

Based on the results of the regression test on the results of learning motivation and student cognitive learning outcomes in Figure 3., it is known that the price of $\mathrm{r}=$ 0.820 , which means that student learning motivation is related to student cognitive biology learning outcomes where the level of closeness of the relationship between variables $\mathrm{X}_{2}$ and $\mathrm{Y}$ is included in the very strong category with the Sig value. $0.00<0.05$. The value 
of the correlation coefficient $\left(\mathrm{R}^{2}{ }_{\mathrm{X} 2 \mathrm{Y}}\right)$ is 0.673 , so the contribution of students' interest towards the cognitive learning biology by $67 \%$.

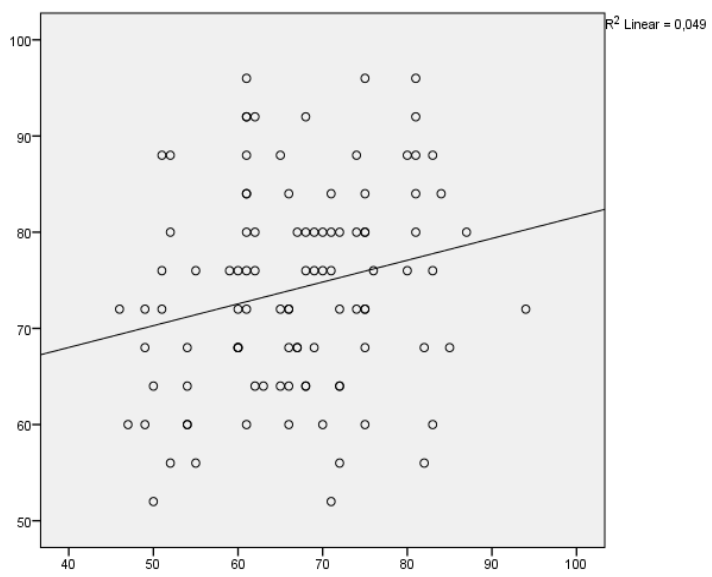

Figure 4. The Relationship between Parents' Attention and Biological Cognitive Learning Outcomes

Based on the results of the regression test on the results of parents' attention and the results of students' cognitive learning $r$ in Figure 4, it is known that the price of $r=0.221$, which means that the parents' attention is related to the cognitive biology learning outcomes of students where the level of closeness of the relationship between variables $\mathrm{X}_{3}$ and $\mathrm{Y}$ is included in the low category with $\mathrm{Sig}$ value $0.00<0.05$. The value of the correlation coefficient $\left(\mathrm{R}^{2}{ }_{\mathrm{X} 3 \mathrm{Y}}\right)$ is 0.469 , so the contribution of students' interest towards cognitive achievement of biology at $4 \%$.

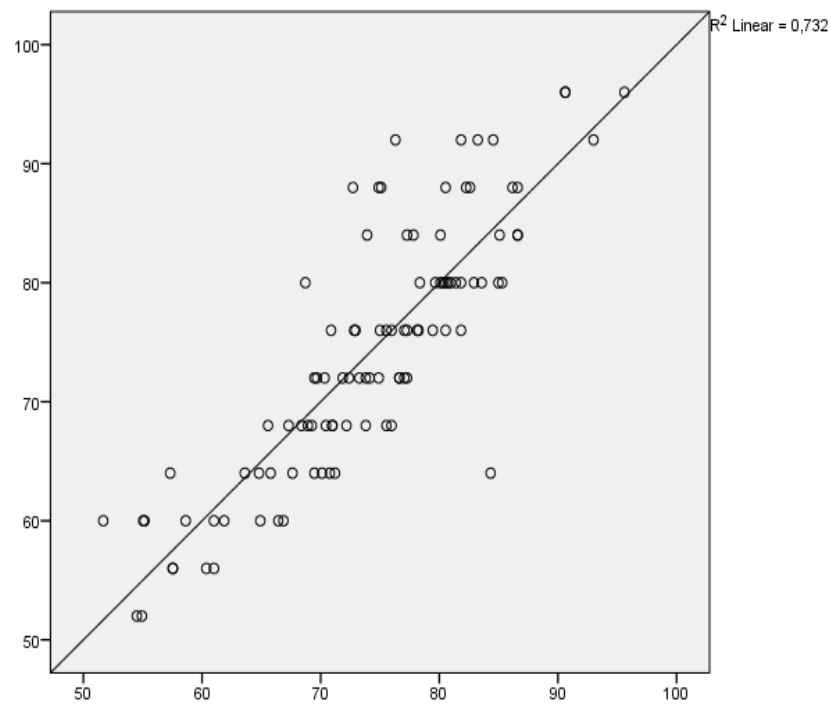

Figure 5. Relationship of Interest and Motivation on Student Cognitive Learning Outcomes

Based on the results of the regression test on the results of interest and motivation on students' cognitive learning outcomes in Figure 5, it is known that the price of $\mathrm{r}=$ 0.855 , which means that student interest and motivation are related to student cognitive biology learning outcomes where the level of closeness of the relationship between variables $\mathrm{X}_{1}$ and $\mathrm{X}_{2}$ with $\mathrm{Y}$ includes in the very strong category with a Sig value of 0.00 
$<0.05$. The correlation coefficient value $\left(\mathrm{R}_{x 1 \times 2, \text { y }}\right)$ is 0.732 , so the contribution of parental interest and attention together to the cognitive biology learning outcomes is $73 \%$.

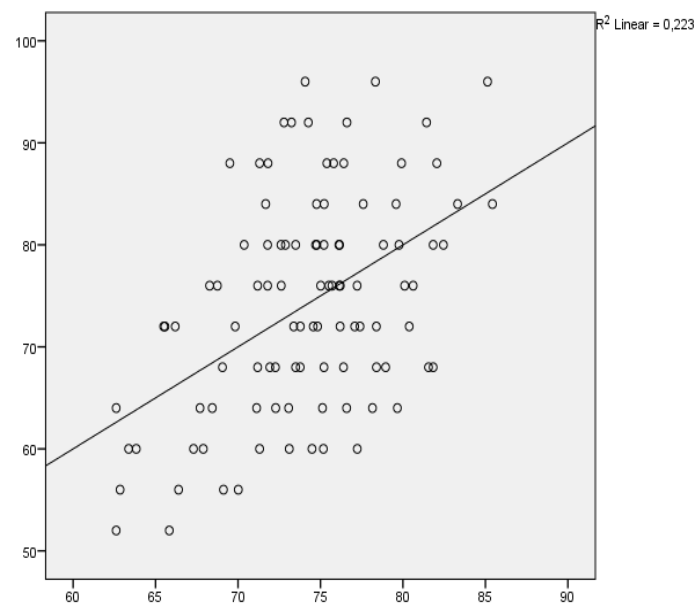

Figure 6. Relationship between Parents' Interests and Attention

Based on the results of the regression test on the results of parental interest and attention to student cognitive learning outcomes in Figure 6., it is known that the price of $r$ $=0.473$, which means that the interest and attention of students' parents is related to the cognitive biology learning outcomes of students where the level of closeness of the relationship between the variables $\mathrm{X}_{1}$ and $\mathrm{X}_{3}$ where $\mathrm{Y}$ is included in the medium category with a Sig value of $0.00<0.05$. The correlation coefficient value $\left(\mathrm{R}_{x 1 \times 3, y}\right)$ is 0.514 , so the contribution of parental interest and attention together to the learning outcomes of cognitive biology is $22 \%$.

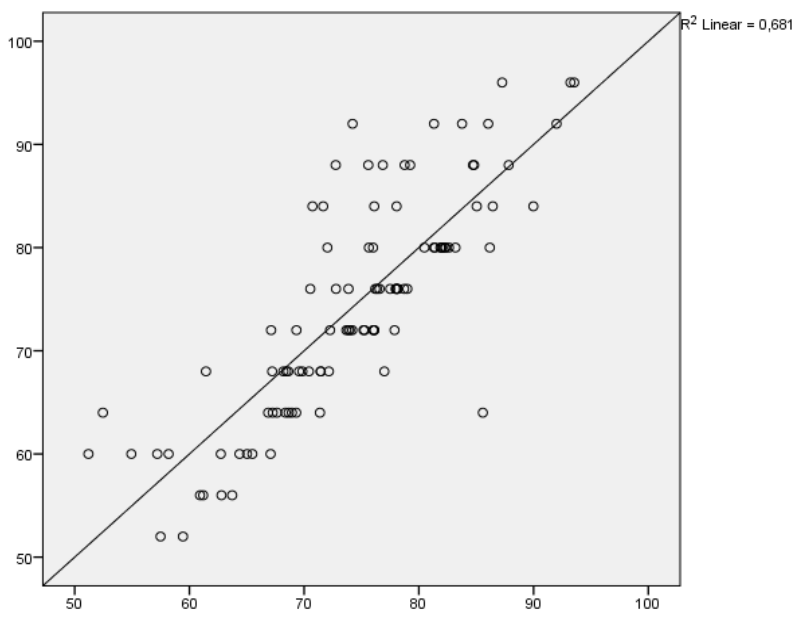

Figure 7. The Relationship between Parents' Motivation and Attention on Learning Outcomes

Based on the results of the regression test on the results of the motivation and attention of parents on student cognitive learning outcomes in Figure 7., it is known that the price of $\mathrm{r}=0.825$, which means that the motivation and attention of the parents of students are related to the cognitive biology learning outcomes of students where the level of closeness of the relationship between the variables $\mathrm{X}_{2}$ and $\mathrm{X}_{3}$ where $\mathrm{Y}$ is included in the medium category with a Sig value of $0.00<0.05$. 


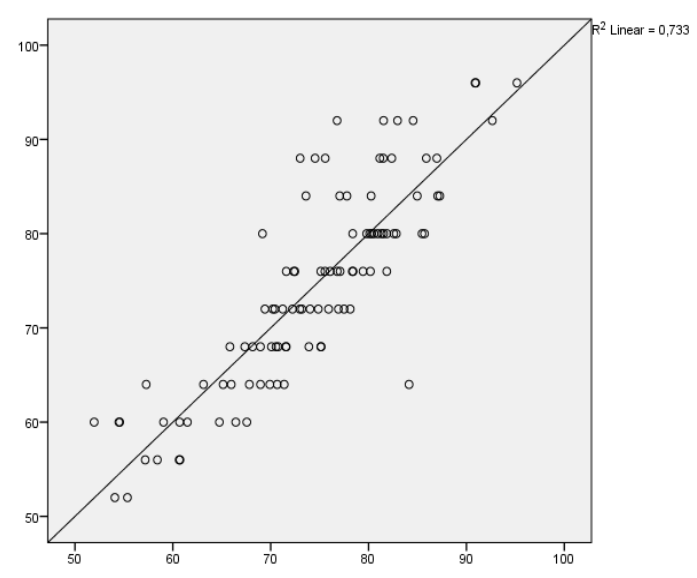

Figure 8. Relationship between Parents' Interests, Motivation and Attention on Learning Outcomes

Based on the results of the regression test on the results of interest, motivation and parental attention to students 'cognitive learning outcomes in Figure 8, it is known that the price of $\mathrm{r}=0.856$, which means that the interest, motivation and attention of students' parents are related to the cognitive biology learning outcomes of students where the level of closeness of the relationship between variable $\mathrm{X}_{1}, \mathrm{X}_{2}$ and $\mathrm{X}_{3}$ with $\mathrm{Y}$ included in the very strong category with a Sig value of $0.00<0.05$, the hypothesis is null $\left(\mathrm{H}_{\mathrm{o} 7}\right)$ which states that there is no relationship between interest, motivation and parental attention together on cognitive learning outcomes biology of students in the cross-interest family at SMAN Percut Sei Tuan was rejected, so the alternative hypothesis $\left(\mathrm{H}_{\mathrm{a} 7}\right)$ was accepted. This means that there is a relationship between interest, motivation and parental attention together on the cognitive biology learning outcomes of students in cross-interest clumps at SMAN Percut Sei Tuan. The result of the contribution of interest, motivation and parental attention together on the learning outcomes of cognitive biology is $73 \%$.

\subsection{Discussion}

Based on research (Ulfah and Ichsan, 2015) it is said that students who have strong motivation and interests with students who have weak interests and motivations will have differences. This difference will be evident with the persistence and efforts to succeed in learning. To be successful in learning, a student needs to be motivated to learn. With motivation, students become more passionate, feel happy, and excited in carrying out learning activities so that learning activities can run smoothly and students can understand lessons better (Pramitasari, et al . 2011).

The importance of motivation to learn is because motivation is a force that drives someone to achieve certain goals. motivation is very necessary in learning, because basically a student will be motivated in learning to achieve his desires. Without motivation, a child or students will not feel comfortable in learning, and these children usually do not want to follow the learning process. Therefore, in order to increase students' interest in learning, motivation to learn is needed so that the learning process runs smoothly (Fauziah, et al . 2017).

Parents are the foundations of education first and foremost because all the knowledge, attitudes and skills of children are obtained first from the parents. Educational problems, especially problems related to children's learning, are not only the responsibility of the teacher, but also the responsibility of parents, because most children's activities are in the household (family) environment. Parents play an important function and role in 
improving their children's education. Parents' attention can be seen from their efforts to provide adequate learning facilities. Parents' attention is the process of providing parental assistance (father and mother or other people responsible for the child) to their children, providing study guidance at home, encouraging learning, giving direction on the importance of learning, paying attention to the needs of tools that support learning for increase children's learning motivation so that they can obtain optimal learning achievement (Endriani, 2016).

However, the completeness of children's learning facilities does not absolutely guarantee children's learning success if it is not followed by the attention of parents shown every day. Some forms of parental attention are providing and managing children's learning time, helping to solve children's problems, monitoring children's learning and providing learning facilities, which include equipment such as buying notebooks, textbooks, dictionaries, providing comfortable children's learning places, and so on. will help fluency in learning. Students who get attention from their parents have high learning motivation. Motivation to learn plays an important role in learning activities. Motivation to learn is the motivation that exists in students to carry out learning activities in order to achieve optimal achievement, besides that the function of learning motivation is in terms of growing passion, feeling happy and enthusiastic about learning. Students who have a passion for learning will more easily understand the learning material, so that learning objectives will be achieved.

\section{Conclusion}

Based on the results of research and discussion, several conclusions can be drawn including the following:

1. There is a significant relationship between student interest in cognitive biology learning outcomes and the acquisition of scores $(\mathrm{r}=0.459 ; \mathrm{p}=0,000)$ which is classified in the moderate category.

2. There is a significant relationship between student motivation on the cognitive learning outcomes of biology with the acquisition value $(r=0.820 ; p=0.000)$ which is classified as very strong.

3. There is a significant relationship between parental attention to cognitive biology learning outcomes with the acquisition of values $(\mathrm{r}=0.221 ; \mathrm{p}=0.000)$ which is classified in the low category.

4. There is a relationship between interest and motivation together on the cognitive learning outcomes of biology with the acquisition of value $(r=0.855 ; p=0.000)$ which is in the very strong category.

5. There is a significant relationship between parental interest and attention together on cognitive biological learning outcomes with the acquisition of values $(r=0.473 ; p$ $=0.000)$ which is in the moderate category.

6. There is a significant relationship between the motivation and attention of parents together on the cognitive learning outcomes of biology with the acquisition of value $(r$ $=0.825 ; \mathrm{p}=0.000)$ which is in the very strong category.

7. There is a significant relationship between the interest, motivation and attention of parents together on biological cognitive learning outcomes with the acquisition of values $(r=0.856 ; p=0.000)$ which belong to the very strong category. 


\section{References}

Djamarah, S. B. 2006. Strategi Belajar Mengajar. Jakarta: Rineka Cipta.

Dumanauw, S. 2017. Pengaruh Perhatian Orang Tua Terhadap Motivasi Belajar Siswa Kelas VI SD Inpres Malalayang II Manado. Jurnal Forum Pendidikan, 3(2), 93-99

Fauziah, A. Rosnaningsih, A dan Azhar, S. 2017. Hubungan Antara Motivasi Belajar Dengan Minat Belajar Siswa Kelas IV SDN Poris Gaga 05 Kota Tanggerang. Jurnal JPSD. 4(1).

Hasyim, B dan Iqbal, M. 2018. Pengaruh Minat Belajar Terhadap Hasil Belajar Biologi Siswa SMA Se Kota Stabat. Jurnal Biolokus, 1(2), 109-115

Ibrahim, R. Yaodih, dan Nana. 2010. Perencanaan Pengajaran. Jakarta: Rineka Cipta

Jirana. Nur, S. dan Nurmiati. 2015. Faktor-Faktor Yang Mempengaruhi Kesulitan Dan Minat Belajar Mahasiswa Jurusan Pendidikan Biologi Universitas Sulawesi Barat. Jurnal Saintifik, 1(2), 87-94

Kambuaya, C. 2016. Pengaruh Motivasi, Minat, Kedisiplinan dan Adaptasi Diri Terhadap Prestasi Belajar Siswa Peserta Program Afirmasi Pendidikan Menengah Asal Papua Barat Di Kota Bandung. Social Work Jurnal, 5(2), 106-208

Makmun, A, S. 2012. Psikologi Pendidikan Sistem Pengajaran Modul. Bandung: PT.

Miranti, I. Dwiastuty, N. dan Nurjanah. 2017. Peran Orang Tua Dalam Meningkatkan Hasil Belajar Bahasa Inggris Siswa. Faktor Jurnal Kependidikan, 4(2), 119-124.

Pramitasari, A. Indriana, Y dan Ariati, J. 2011. Hubungan Antara Persepsi Terhadap Metode Pembelajaran Konstekstual Dengan Motivasi Belajar Biologi Siswa XI IPA SMAN 1 Pangkalan Kerinci Riau, Jurnal Psikologi Undip. 9(1).

Samben, S. 2014. Pengaruh Minat dan Kebiasaan Belajar Terhadap Prestasi Belajar. Jurnal Elektika, 2(1), 60-66.

Sitorus, H. (2019). The Effect of Learning Strategy and Thinking Ability on The Students' Learning Outcomes in Economics Subject of XI Social Students in Senior High School State 1 in Pematang Siantar. Budapest International Research and Critics in Linguistics and Education (BirLE) Journal. p. 451-460.

Slameto. 2010. Belajar dan Faktor-Faktor Yang Mempengaruhi. Jakarta: Rineka Cipta.

Syah, M. 2015. Psikologi Belajar. Jakarta : PT Raja Grafindo Persada.

Yusrizal, Y. (2020). Pengaruh Pendekatan Etnopedagogi dan Motivasi Belajar terhadap Hasil Belajar IPS Siswa di SD Negeri Panton Luas Baru. Jurnal Ilmiah Maksitek, 5(3), 84-92.

Yusrizal, Y., Hajar, I., \& Tanjung, S. (2019). Analysis of Elementary School Teachers' Ability in Using ICT Media and Its Impact on the Interest to Learn of Students in Banda Aceh. Budapest International Research and Critics in Linguistics and Education (BirLE) Journal, 2(3), 45-57. 